Special thanks go to John Worthington, Royal Canadian Mounted Police, for assistance during several aerial surveys. We gratefully acknowledge the contributions of Cliff Matthews, Canadian Wildlife Service, Ross Hanson, U.S. Bureau of Sport Fisheries and Wildlife, and Wayne Renaud who were instrumental in our discovery of the Trumpeter breeding area in west-central Saskatchewan.

${ }^{\prime} \mathrm{BANKO}$, W. E. 1960. The Trumpeter Swan. North American fauna, 63, U.S. Dept. Interior, Washington. $214 \mathrm{pp}$.

BANKO, W. E. and R. H. MacKAY. 1964. Our native swans. In Waterfowl Tomorrow. U.S. Dept. of Interior, Washington. $770 \mathrm{pp}$.

BARD, F. C. 1953. The Trumpeter Swan. Blue Jay, I 1:26-27.

'DELACOUR, J. 1954. The waterfowl of the world. Vol. 1. Country Life Ltd., London. 284 pp.

EVENDEN, F. G. 1969. Report of Committee on Conservation, 1969. Auk, 86:738-744.
"LAHRMAN, F. W. 1961. A second pair of Trumpeter Swans nesting in Saskatchewan. Blue Jay, 19:18-19.

'LISTER, R. 1951. Trumpeter S'wans breeding in the Cypress Hills of Alberta. Can. Field-Nat., 65:157-158.

${ }^{*}$ MORRIS, W. A. 1971. Birds of British Columbia. In Canadian Wildlife Service '71. Canadian Wildlife Service, Ottawa. 88 pp.

"MUNRO, D. A. 1962. Trumpeter Swans. Canadian Audubon, 24:65-69.

"NIEMAN, D. J. 1971. A proposed plan for management of the Cypress Hills Trumpeter Swans. Unpublished report, Canadian Wild life Service. 8 pp.

"NIEMAN, D. J. 1972. Cypress Hills, Saskatchewan. Trumpeter Swans. Proceedings Second Trumpeter Swan Society Conference, Grande Prairie, Alberta. pp. 27-28.

12NIEMAN, D. J. 1972. Trumpeter Swans in the Cypress Hills. Blue Jay, Vol. XXX No. 2.

${ }^{1:}$ SYMONS, R. D. 1967. Hours and the birds. Univ. of Toronto Press, Toronto, $224 \mathrm{pp}$.

${ }^{4}$ TA VER NER, P. A. 1949. Birds of Canada. The Musson Book Co. Ltd., Toronto. 447 pp.

\title{
MORE HUDSONIAN GODWITS IN SASKATCHEWAN
}

\author{
by WAYNE C. HARRIS*
}

The Hudsonian Godwit has been onsidered an uncommon migrant in askatchewan. Until 1969 it was listed $n$ the Red Data Book as being a rare pecies. ${ }^{3}$ Even before they were emoved from the rare and enangered species list, Hudsonian Godits migrated through Saskatchewan, ut always in small numbers and inrequently. Most previous dates are of

Box 93

aymore, Sask

$0 \mathrm{~A} 3 \mathrm{~J} 0$ spring migrants. Fall migrants were considered rare. In fact, until 1970 numbers of Hudsonian Godwits over a flock of 15 had not been reported during fall migration. In 1970 and 1971 Gollop reported concentrations of Hudsonian Godwits for July and August and summarized all previous fall records from the Prairie Provinces to central Texas.' The following note reports more recent fall observations of Hudsonian Godwits in Saskatchewan. 


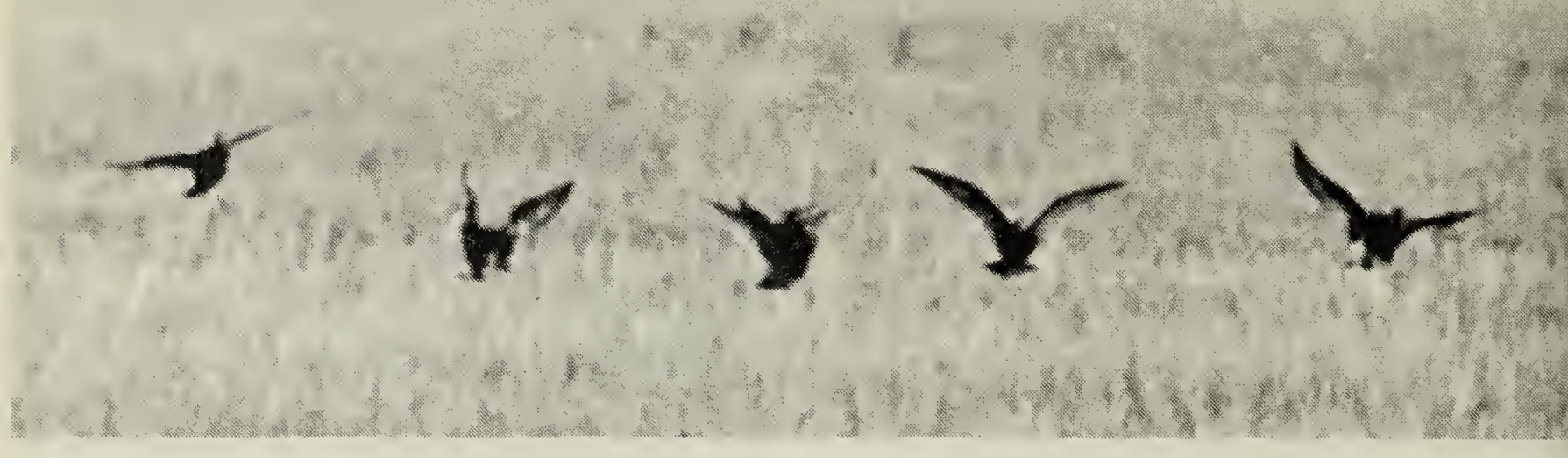

Hudsonian Godwits

Fred W. Lahrm:

In 1972 concentrations were not so spectacular as in 1971 . On July 20, J. B. Gollop counted 89 Hudsonian Godwits with 122 Marbled Godwits on Porter Lake (11 miles eastnortheast of Saskatoon) and on August 20, Wayne Renaud counted 67 Hudsonian Godwits with 176 Marbled at the same locality.

In 1973, numbers reached the highest ever on Porter Lake. The author and V. J. Lieffers counted $850 \pm$ Hudsonian Godwits with about 200 Marbled Godwits, on July 6. By July 9 their numbers had increased to $1,150 \pm$ individuals. On July 14 , in the early morning, Gollop counted 133 Hudsonian with 36 Marbled, but by mid-afternoon of the same day numbers had jumped to more than 600 when counted by S. J. Shadick. Shadick visited Porter Lake again on July 18 and estimated 300 remaining Hudsonian Godwits. On July 22,

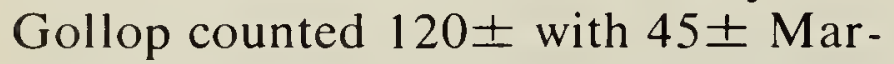
bled Godwits. By this time the lake was almost-dry. The godwits were last seen here on July 24 when the author, D. G. Hjertaas and J. E. Polson counted 111 Hudsonian with 30 Marbled. On July 28, Porter Lake was completely dry and no godwits remained.

Until 1973, Porter Lake was the only area in the entire Great Plains region (Saskatchewan to Texas) where over 50 Hudsonian Godwits had bee seen and reported. This concentratio on a single area is amazing; did all $c$ the godwits migrating from the arcti breeding grounds via the "plair" route" find this area? Only an or casional bird or more infrequently flock of 20 was recorded anywher else on the Great Plains. In 1973, fo the first time, numbers of Hudsonia Godwits were reported elsewhere tha at Porter Lake.

At Foam Lake (approximately 12 miles east of Porter Lake), on th evening of July 17 , a flock of 135 Huc sonian Godwits, associated with 3 Marbled, were counted by the auth and V. J. Lieffers while employed $b$ the Canadian Wildlife Service. Just hours earlier this particular flat ha not a single godwit. By mid-mornir of the next day their number had ris to 394 with about 70 Marbled. ${ }^{2} \mathrm{~W}$ then left the area and no further obse vations were made.

On July 28, 1973, the author ar Wayne Renaud found a loose flock 78 Hudsonian Godwits with $45 \mathrm{Ma}$ bled, on a small lake, locally call Catherwood Lake, approximately miles south of Perdue (approximate 50 miles west of Porter Lake). T next day 4 Hudsonians with : Marbled Godwits and 5 Long-bill Curlews were seen on Vanscoy Lake Perdue. 
Other observations of Hudsonian Godwits during 1973 included 12 with 30 Marbled counted by Gollop at Blucher (about 15 miles southsoutheast of Porter Lake) on July 28 and 7 on August 3, again at Blucher. The author also saw a single bird at St. Denis (10 miles east of Porter Lake) on August 21.

The peak in godwit numbers at Porter Lake seemed to be on or around July 9. After this date a steady decrease occurred. At the same time smaller concentrations began appearing at other locations. Were the birds at Porter Lake dispersing to other locations? If this were true, several interesting questions arise: 1) Why did they disperse in several directions instead of all going approximately the same direction as they apparently had done in coming to Porter Lake? 2) Why did they not coninue southward?

Another interesting point arises when considering the July 14 counts at Porter Lake; in the early morning only 133 Hudsonian Godwits were obseryed compared to more than 600 in the afternoon. This seems to indicate that more birds had arrived in the area presumably from the north. If this vere true, then migration was still unler way and flocks seen at other ocations could easily have been new higrants. The fact that godwits were at he same latitude and 175 miles apart Perdue to Foam Lake) seems to avour the theory that these birds were ew migrants rather than birds dispering from Porter Lake.

If so, then the number of birds higrating through Saskatchewan, in 973, numbered over 2000. This robably represents approximately $\%$ of the estimated population of ludsonian Godwits in North America.

A. Hagar in a letter to J. B. Gollop, ated August 10,1971, estimated the ptal population of Hudsonian God- wits at 30,000 absolute minimum, more probably 40,000 to 50,000 individuals.

The habitat used by these birds appears to be extremely variable. Gollop described Porter Lake as "an alkali flat about two miles long and averaging less than half a mile in width. It does not always have water through August ... The lake is more than 99\% devoid of emergent (and probably submergent) vegetation".' It is an example of an extremely alkaline lake. Catherwood Lake is much less alkaline. It is about 2 miles long and averages about 500 yards in width. The dominant vegetation was Water Milfoil (Myriophyllum exalbescens). The water was very shallow and the milfoil was a mat in both water and along the shore. Foam Lake, on the other hand, is entirely different. It is a large lake (approximately 15 square miles) choked with cattail (Typha latifolia) and bulrush (Scirpus spp.), with the deeper, centre portion being open water. It has a very low salinity. The site where the godwits were found was again a flat open area, the only one on the lake. It was about $1-1 / 2$ acres in size and had been formed by a mound of dirt pushed up to form a dike between this area and the main lake in a year of low water. When water levels are normal this pond is part of the lake. This year by mid-July it contained water about 6 inches deep at its deepest point. The dominant vegetation in this small area was Needle Spike-rush (Eleocharis acicularis) which formed a mat both under water and on the shoreline. This diversity of habitat suggests that habitat is not likely the only factor determining where godwits stop. Why they are not seen elsewhere in fall between here and Texas is a good question. Possibly they do stop at other small lakes on the plains which are not frequented by competent observers at the appropriate time. 
I would like to thank C. S. Houston and W. E. Renaud for their comments on the manuscript, the Canadian Wildlife Service for permission to use data collected during the past summer and J. B. Gollop for his assistance in obtaining data.
GOLLOP J. B. 1971. Summer records of Huc. sonian Godwits near Saskatoon, Saskatchewar Blue Jay 29(3):132-134.

${ }^{2}$ HARRIS W. C. and V. J. LIEFFERS. 197 Foam Lake - natural history notes and speci lists. Canadian Wildlife Service Unpublishe Report. 21 pp.

"VINCENT J. 1966. Red Data Book, Volume The Aves. International Union For Conse vation of Nature and Natural Resources.

\title{
ROCK WREN AT SPRAGUE, MANITOBA
}

\author{
by DAVID R. M. HATCH and HERBERT W. R. COPLAND*
}

On the morning of October 11 , 1972, a Manitoba Museum of Man and Nature field party consisting of Dr. Robert Wrigley, Jack Dubois, Calvin Cuthbert and the authors identified a Rock Wren (Salpinctes obsoletus) at the farmhouse of Dr. George Lammers, 9 miles north of Sprague, Manitoba. The junior author's attention was attracted by the melodious song, which was unfamiliar to him, however he did not locate the bird. Approximately one hour later Cuthbert observed the bird and called the authors. The bird was wary but reluctant to leave the immediate locale of the farm buildings. Cuthbert and the authors, using binoculars and a telescope obtained excellent observations of the wren and the following details were noted. The bird was the size of a White-breasted Nuthatch. The tail, which was finely barred with grey and brown throughout its length, had a broad terminal band of black, bordered on the

\footnotetext{
* Manitoba Museum of Man and Nature,

190 Rupert Avenue,

Winnipeg, Manitoba.

R3B ON2
}

outside by orange buff. Besides th key distinguishing feature, the rum was rusty, the breast finely streake the crown and back grey-brown an the bill about $1 / 2$ inch long and curve slightly downward.

The bird kept returning to a pile scrap lumber; however, it als frequented a derelict binder and ty deserted buildings. All five observe had the bird under observation an were able to verify details. The seni author was previously familiar wi the species having observed Ro Wrens in Saskatchewan and $t$ western United States. The bird, bei seen so far east of its normal range ar at such a late date, was collected substantiate the presence of the speci in the province and is specimen $N$ MMMN 3236 in the study skin colle tion of the Manitoba Museum of $\mathbf{M}$ and Nature. It proved to be an adi male. Godfrey in listing the $e$ tralimital records for this species Canada gave Churchill as the mo easterly record. ${ }^{3}$ Since th publication, there have been two $\mathrm{C}$ 